\title{
Piotr Czakon
}

\section{NOWA MARTWA DZIELNICA? KATOWICKA STREFA KULTURY W PERSPEKTYWIE MYŚLI URBANISTYCZNEJ JANE JACOBS}

\begin{abstract}
Abstrakt. Wywód skoncentrowany jest na przykładzie Katowickiej Strefy Kultury - nowej dzielnicy powstałej w wyniku adaptacji terenów zamkniętej kopalni Katowice. Oprócz znanego od wielu lat Spodka, niedawno otwartego gmachu Narodowej Orkiestry Symfonicznej Polskiego Radia (NOSPR) i Międzynarodowego Centrum Kongresowego (MCK), w skład katowickiej Strefy Kultury wchodzi także nowe Muzeum Śląskie. Nowe budynki zyskały rozgłos i uznanie w środowisku architektów. Pojawiają się również głosy krytyki odnośnie do sposobu realizacji inwestycji - skupienia gmachów o podobnej funkcji w jednym miejscu. W tekście wskazano, że nowa dzielnica została zaprojektowana zgodnie z modernistycznym paradygmatem w urbanistyce (segregacja funkcji, rozluźnienie zwartości zabudowy). Nie jest to niczym dziwnym, zważywszy na architektoniczne tradycje Katowic. O wiele istotniejsze są jednak społeczne konsekwencje modernistycznego planowania przestrzeni, na które wskazują jego krytycy. Szczególne miejsce wśród nich zajmuje Jane Jacobs - autorka słynnej książki Śmierć i życie wielkich miast Ameryki. Odwołując się do myśli Jacobs, przeanalizowano przestrzeń Strefy Kultury. Omówiono takie zagadnienia, jak: rozplanowanie budynków, układ ulic, zróżnicowanie funkcjonalne. Niestety, wnioski badania nie są optymistyczne. Strefa Kultury jest mało zróżnicowaną i odseparowaną od reszty miasta przestrzenią. Zmaga się ona także z małym zainteresowaniem mieszkańców.
\end{abstract}

Słowa kluczowe: katowicka Strefa Kultury, Jane Jacobs, rewitalizacja, przestrzeń publiczna.

\section{Wstęp}

Rewitalizacja terenów poprzemysłowych to jedno z najważniejszych wyzwań, z jakim zmagają się miasta konurbacji górnośląskiej. Problem ten w szczególności dotyczy Katowic. Jeszcze u schyłku lat 90. XX wieku w ścisłym centrum stolicy województwa funkcjonowały trzy duże zakłady przemysłowe: huta Baildon oraz kopalnie Kleofas ${ }^{1}$ i Katowice. Tereny po upadłej w 2001 roku hucie

${ }^{*}$ Uniwersytet Śląski, Wydział Nauk Społecznych, 40-007 Katowice, ul. Bankowa 11, pczakon@us.edu.pl.

${ }^{1}$ Do 1990 roku kopalnia nosiła nazwę Gottwald. 
Baildon nie zostały w pełni zagospodarowane i wciąż stanowią wielohektarową wyrwę w tkance miasta. Pewne kontrowersje wzbudza rewitalizacja przestrzeni pozostałej po kopalni Kleofas (wygaszonej w 2004 roku), którą prywatny inwestor zabudował, tworząc największe w południowej Polsce centrum handlowe i grodzone osiedle. Musiało minąc ponad dziesięć lat, aby włączenia do struktur miejskich doczekał się teren po zamkniętej w 1999 roku kopalni Katowice. W latach 2011-2015, kosztem ponad 1 mld zł, w miejscu tym wybudowanych zostało kilka gmachów użyteczności publicznej, które - zgodnie z zapewnieniami władz Katowic - tworzą nową dzielnicę miasta. Oprócz znanego od wielu lat Spodka, w skład katowickiej Strefy Kultury wchodzą niedawno otwarte siedziby Narodowej Orkiestry Symfonicznej Polskiego Radia (NOSPR), Międzynarodowego Centrum Kongresowego (MCK) i Muzeum Śląskiego.

Wspomniane gmachy zyskały medialny rozgłos i uznanie w środowisku architektów, o czym świadczą liczne nagrody i wyróżnienia. Jednocześnie można spotkać się z pewnymi słowami krytyki odnośnie do sposobu realizacji inwestycji i skupienia budynków o zbliżonej funkcji w jednym miejscu. Najbardziej dobitnym wyrazem pojawiających się wokół Strefy Kultury kontrowersji jest uzyskanie przez rozpatrywaną inwestycję nominacji do X edycji organizowanego przez katowickie Stowarzyszenie Moje Miasto konkursu na najgorszą realizację w przestrzeni publicznej - czyli „Betonowej Kostki”.

Ważne pytanie, jakie należy zadać w przypadku katowickiej Strefy Kultury, dotyczy jej funkcjonowania w kontekście zespołu miejskiego. Oznacza to konieczność wyciągnięcia wniosków odnośnie do całej dzielnicy, a nie poszczególnych, wchodzących w jej skład inwestycji i ich architektonicznych walorów. Należy zastanowić się nad sposobem rozplanowania Strefy Kultury, jej powiązaniem z resztą miasta, dominującą formą zabudowy oraz sposobami jej wykorzystywania przez mieszkańców. Zaproponowana tu analiza będzie pierwszym tego typu kompleksowym przedsięwzięciem badawczym. Co więcej, poczynione wnioski będą miały istotne znaczenie nie tylko z punktu widzenia Katowic, ale także przyszłych inwestycji związanych z rewitalizacją przestrzeni postindustrialnych. Jedyne, co pozostaje przed przystapieniem do rozważań, to wybór adekwatnej perspektywy teoretycznej.

Na miasto spoglądać można z różnych stron i przy uwzględnieniu odmiennych płaszczyzn analitycznych. Przykładowo, Bohdan Jałowiecki i Marek S. S z c ze pań s ki (2006: 13-14) w poczet klasycznych stanowisk badawczych zaliczają: szkołę chicagowską, szkoły kulturalistyczne, szkoły neoekologiczne, szkoły konwencjonalne, szkoły makrostrukturalne i strukturalno-funkcjonalne oraz szkoły humanistyczne. Zbliżoną typologię ujęć teoretycznych przytacza w swoim podręczniku socjologii miasta również Andrzej M a je r (2010: 79).

Artykuł ten zawiera propozycję wyjścia poza klasyczną typologię ujęć socjologii miasta. Niejako obok przytoczonej klasyfikacji sytuują się poglądy na przestrzeń zurbanizowaną amerykańsko-kanadyjskiej działaczki miejskiej i dzien- 
nikarki Jane Jacobs. Choć autorka ta nie była związana z żadnym ośrodkiem akademickim, to sformułowane przez nią obserwacje zyskały rozgłos w środowisku zachodnich urbanistów i stały się jedną z płaszczyzn socjologicznej analizy miasta (P o bło cki 2014: 462-465). Za najważniejsze dzieło Jacobs uważa się Śmierć $i$ życie wielkich miast Ameryki. Musiało minąć ponad pięćdziesiąt lat od pierwodruku książki (1961), aby to kluczowe dla rozwoju myśli urbanistycznej wydawnictwo doczekało się polskiego tłumaczenia.

\section{Sposób rozpatrywania przestrzeni zurbanizowanej przez Jane Jacobs}

Zaproponowany tu namysł wymaga przywołania kluczowych założeń, podług których autorka Śmierci i życia wielkich miast Ameryki rozpatrywała przestrzeń zurbanizowaną. Co prawda, w rozdziale wprowadzającym do książki Jacobs stwierdza, że publikacja ta jest wyrazem buntu wobec modernistycznej strategii rewitalizacji Nowego Jorku, ale kluczem do zrozumienia pracy jest rozdział ją wieńczący. Jacobs zestawia w nim dwa odmienne sposoby oglądu miasta: fizyczny i organicystyczny. Pierwsza z wizji, czerpiąc inspiracje z dorobku nauk fizycznych, traktuje miasto jako zagadnienie proste lub niezorganizowanie złożone $^{2}$ ( a c o b s 2014: 443-446). Wedle takiego ujęcia wszelka analiza procesów miejskich może ograniczać się do badania współzależności między dwoma wybranymi wyabstrahowanymi mierzalnymi cechami miasta. To mylne spojrzenie na kwestię miejska, reprezentowane przez większość środowiska urbanistów, sięga swoimi korzeniami do tez Ebenzera Howarda i idei miasta ogrodu (t a m że: 446). Howard, „niczym XIX-wieczny fizyk analizujący proste zagadnienie o dwóch zmiennych", uwzględnił dwie wartości (liczbę ludności i liczbę miejsc pracy), aby zaproponować koncentryczną strukturę miejską o odseparowanych funkcjach produkcyjnych i mieszkalnych oraz charakterystyce zabudowy małego miasteczka. Choć wizja Howarda, jako powstała w odpowiedzi na udrękę życia w miastach epoki rewolucji przemysłowej, nie pozbawiona była zalet, to wyrządziła wiele szkód w myśli o mieście. Wedle Jacobs, projekt miasta ogrodu ufundowany został bowiem na mylnej koncepcji ontologicznej człowieka jako „szlachetnego dzikiego". Wszelkie próby uzdrowienia sytuacji w miastach poprzez implementację wiejskiego stylu życia stoją zatem w sprzeczności z natura człowieka i jako takie skazane są na niepowodzenie.

Wraz z upowszechnieniem się koncepcji idealnego miasta ogrodu w latach 20. XX wieku zachodnią urbanistykę opanowały wizje i metody odwołujące się do fizycznego sposobu traktowania zagadnienia miejskości. Najważniejsze z nich

2 Pod pojęciem tym kryje się postawa upatrująca w sposobie funkcjonowania miasta chaos, w którym nie występują żadne prawidłowości. 
to ruch decentrystyczny, strefowanie zabudowy, waloryzacja przestrzeni otwartych i parkowych, upowszechnienie analizy statystycznej i odgórnych matematycznych programów planowania miast (t a m ż e: 448). W opinii Jacobs, dwoma najbardziej skrajnymi (i szkodliwymi) przejawami pochłonięcia urbanistyki przez ujęcie mechanistyczne były projekty przestrzeni nawiązujące do wizji miasta promiennego i ruchu City Beautiful (t a m ż e: 40-44).

Pierwsza z wizji, koncepcja miasta promiennego, ukuta została w 1922 roku przez Le Corbusiera. Propozycja francuskiego architekta przedstawiała majestatyczne miasto-park, cechujące się regularną i symetryczną siatką ulic, ścisłym podziałem kwartałów wedle funkcji oraz skupieniem ludności w ramach jednakowych wieżowców (P a s zk ow s k i 2011: 165-166). Natomiast druga z wizji, City Beautiful, oznacza zrodzoną z końcem XIX wieku tendencję do „wznoszenia monumentalnych gmachów publicznych w stylu neoklasycystycznym i wytyczania szerokich reprezentacyjnych alej" (J a c o b s 2014: 43). W ramach idei City Beautiful w wielu miastach powstały pokazowe, monofunkcyjne dzielnice kulturalne i administracyjne. Choć z czasem obie idee straciły nieco na znaczeniu i nie występują już w czystej postaci, to w zmienionej, połączonej formie nadal kształtują sposób organizowania miejskiej przestrzeni. Dlatego w wielu miastach wciąż obecna jest moda na separację budynków o różnej funkcji, zmniejszania gęstości zabudowy, budowania monumentalnych dzielnic kulturalnych lub administracyjnych (t a m ż e: 44, 384).

Tymczasem te oparte na symplicystycznych założeniach wizje stoją w sprzeczności ze złożona, acz uporządkowaną naturą miast. W tym miejscu przechodzimy do referowania drugiej z wyróżnionych przez Jacobs perspektyw percepcji miasta - czyli preferowanej przez nią wizji organicystycznej. Miasto jest bowiem przykładem zorganizowanej złożoności i może być rozpatrywane analogicznie do taktyki opisywania organizmów. Szczególna rola przypisywana jest tutaj technikom obserwacji i szczegółowemu oglądowi. Dlatego wedle autorki Śmierci i życia wielkich miast Ameryki drogą do zrozumienia miejskiego życia jest spojrzenie z bliska na codzienne sytuacje i praktyki ( $t$ a $m$ ż e: 32 ). Ogląd miasta wiąże się zatem z uwzględnieniem wielu przenikających się zmiennych, które nie tworza jednak chaosu. Zgodnie z proponowaną przez Jacobs perspektywă, naturalnym stanem dla dobrze funkcjonujących kompleksów miejskich jest istnienie ,[...] możliwie złożonego i najściślejszego splotu różnorakich funkcji, które nieustannie wspierają się nawzajem zarówno na planie ekonomicznym, jak i społecznym" (t a m że: 32 ).

Analiza społecznych zachowań ludzi w mieście winna rozpoczynać się już od poziomu ulic i chodników, a następnie obejmować parki oraz miejskie rejony ${ }^{3}$.

3 Jacobs w tym miejscu posługuje się terminem „Neighborhood”, który w polskim wydaniu książki został przetłumaczony na „miejski rejon”. Z kontekstu książki wywnioskować można, że pojęcie to oznacza osiedle lub fragment dzielnicy mieszkalnej. 
Wszystkim tym elementom miejskiego pejzażu przypisać można bowiem znaczenie wykraczające poza ich funkcjonalną użyteczność ( t a m ż e: 32 ).

Chodnik wraz z przyległymi do niego ulicami pełni rolę głównej przestrzeni publicznej w mieście. Jest swoistą sceną, na której odbywają się przedstawienia życia codziennego. Od przypisywanego chodnikom (i ulicom) poczucia bezpieczeństwa uzależnione jest przekonanie o bezpieczeństwie w danym rejonie miasta. Dokonywanej przez Jacobs waloryzacji ulic i chodników towarzyszy pomniejszanie znaczenia zieleni miejskiej i parków. Parki są pożyteczne, jeżeli zostały dobrze połączone z resztą miasta i są na tyle atrakcyjne, aby przychodzili do nich ludzie. Analogicznie do pozbawionych ludzkiej kontroli chodników parki mogą negatywnie oddziaływać na otoczenie, obniżając poziom bezpieczeństwa w regionie. Wbrew opiniom wielu urbanistów miejskie rejony - czyli trzeci z poziomów codziennego oglądu miasta - nie powinny mieć cech małomiasteczkowych, zwróconych do wewnątrz jednostek mieszkalnych. Strategia taka prowadzi do ujednolicania i segmentacji miast, wprowadzania $\mathrm{w}$ nich podziału na odseparowane od siebie terytoria ( $\operatorname{ta} \mathrm{m} \dot{z}$ e: $32,52-54,105-126$ ).

\section{Przesłanki ksztaltowania się miejskiej różnorodności}

Aby tak postulowana przez Jacobs miejska złożoność rozwijała się na wszystkich rozpatrywanych poziomach (ulic, chodników, parków, rejonów), zaistnieć muszą pewne okoliczności. Autorka wyróżnia tu cztery zasadnicze warunki brzegowe umożliwiające kształtowanie się bujnej miejskiej różnorodności:

1. Każda dzielnica musi spełniać więcej niż jedną podstawową funkcję;

2. Większość kwartałów zabudowy musi mieć krótkie boki, ulice muszą się często krzyżować;

3. W dzielnicach muszą sąsiadować ze sobą budynki w różnym wieku i stanie;

4. Potrzebne jest odpowiednio wysokie zagęszczenie ludności w dzielnicach (J a c o b s 2014: 164).

Przyjrzyjmy się nieco bliżej każdemu z tych postulatów.

Kiedy w ramach dzielnicy krzyżuje się kilka funkcji, to dzięki temu zapewniana jest w niej stała obecność ludzi o różnych porach dnia. Inaczej rzecz ujmując, generowany jest regularny przepływ mieszkańców przez dany sektor miasta, co w zbawienny sposób oddziałuje na funkcjonowanie ulic i chodników. Użytkując te same ulice, mieszkańcy sprawują społeczną kontrolę nad przestrzenią - zwiększają poziom bezpieczeństwa. W opinii referowanej autorki dobrze zorganizowana dzielnica winna łączyć w sobie dwie odmiany różnorodności: pierwotną i wtórną. Pierwsza z nich (różnorodność pierwotna) ma charakter bardziej oficjalny i wynika z konkretnych funkcji ulokowanych w dzielnicy. Przykładowo są to biura, zakłady przemysłowe i usługowe, punkty rozrywki, które przyciagaja mieszkańców ze względu na zlokalizowanie ich w określonej okolicy. Różnorod- 
ność wtórna oznacza natomiast formy działalności, które powstały w reakcji na te pierwotne i na przybyłych do dzielnicy użytkowników. To właśnie obecność drugiej formy różnorodności przesądza o kolorycie danej dzielnicy. Opowiadając się za różnicowaniem form wykorzystywania dzielnic, Jacobs po raz kolejny negatywnie odnosi się do projektów realizacji monofunkcyjnych stref miejskich. Stwierdza, że monumentalne centra kultury i centra administracyjne „,...] mają tragiczne oddziaływanie na miasta" (t a m ż e: 181). Przejawia się to w tym, że „,...] odizolowują one poszczególne funkcje - a nazbyt często także funkcje użytkowane intensywnie w nocy - od tych części miasta, w których ich brak grozi chorobą" (t a m ż e: 181).

Drugi z wyróżnionych przez Jacobs warunków brzegowych różnorodności odnosi się do znaczenia małych kwartałów zabudowy. Aby miejska przestrzeń dobrze funkcjonowała, nie wystarczy bowiem, aby w ramach dzielnic koncentrowały się zróżnicowane funkcje. Niezbędne jest także umożliwienie mieszkańcom łatwego i szybkiego docierania do tych funkcji. Kiedy kwartały zabudowy są rozległe, a przyległe do nich ulice rzadko się krzyżują, doprowadza to do sytuacji, w której część użytkowników dzielnicy zostaje odseparowana od innych. Mamy wtedy do czynienia z występowaniem długich ścieżek, które rzadko stykają się ze sobą i przez to oddalają od siebie pozornie blisko zlokalizowane punkty. Przeplatające się ulice i małe kwartały są wartościowe, ponieważ sprzyjają misternemu mieszaniu się miejskich funkcji ( $\mathrm{t}$ a m ż e: 198).

Wedle trzeciego z postulatów Jacobs (t a mże: 199) „W dzielnicach muszą sąsiadować ze sobą budynki w różnym wieku i stanie, w tym odpowiednio dużo budynków starych". Nie chodzi tu wcale o obecność obiektów historycznych, lecz o „zwykłe” starsze obiekty charakteryzujące się niższą wartością. Rozległe połacie zabudowy, które wzniesione zostały w zbliżonym czasie, wprowadzaja jednorodność w miejskiej tkance. W ten sposób dochodzi do redukcji kulturowej, demograficznej i gospodarczej różnorodności dzielnicy. Całe strefy wypełnione jednakowo nowymi zabudowaniami powodują jeszcze inne problemy. Najważniejsze z nich to zawyżanie cen najmu lokali usługowych, równomierne starzenie się budynków i inwestycyjna stagnacja. W prosty sposób można to wythumaczyć. Kiedy w jednym momencie powstają nowe kwartały miasta, to wiąże się to z ogromnymi nakładami inwestycyjnymi. Według Jacobs proceder taki zaburza naturalny cykl miejskich procesów gospodarczych. W krótkim czasie jedna strefa miasta staje się beneficjentem ogromnych sum pieniężnych. Skala inwestycji zawyża ceny nieruchomości, co wyklucza z rywalizacji o nie biedniejszych najemców. Przez lata w strefie panuje zastój inwestycyjny, nie następują większe zmiany przestrzenne. Po tym czasie wszystkie zlokalizowane tam gmachy są w jednakowym stopniu niedoinwestowane i zaniedbane (t a m że: 199-210, 305-327).

Czwartym źródłem różnorodności jest dla Jacobs wysokie zagęszczenie ludności w dzielnicach. Postulat ten odnosi się w równej mierze do potrzeby wystę- 
powania wielu użytkowników przestrzeni, jak i zamieszkiwania jej przez odpowiednio wysoką liczbę mieszkańców. Przy czym autorka nie wprowadza tu prostej zasady, że im wyższy współczynnik zagęszczenia, tym lepiej funkcjonuje miasto. Zarówno zbyt niskie, jak i zbyt wysokie zagęszczenie ludności i gospodarstw domowych negatywnie oddziałuje na kształtowanie się miejskiej różnorodności. Na jednym biegunie lokują się osiedla z otwartymi połaciami przestrzeni, w których zabudowa zajmuje między $15 \%$ a $25 \%$ terenu. Ich parkowy charakter determinuje mało efektywny rozkład gospodarstw domowych i wysoką jednorodność. W osiedlach otwartych lokale mieszkalne muszą być jak najściślej zestandaryzowane i umieszczone w rzędach jednakowych bloków z windami. Jak już zostało powiedziane, powoduje to zubożenie przestrzeni publicznych, zmniejszenie społecznej kontroli nad nimi (t a m ż e: 211-227).

Okolice, w których wskaźnik zabudowy sięga $70 \%$ powierzchni, stanowią natomiast przykład z drugiego bieguna skali. Tak wysoki współczynnik zagęszczenia również nie stanowi pożądanego stanu. Życie w rozległych, gęsto zabudowanych kwartałach może być bowiem bardzo opresyjne dla mieszkańców. Zwłaszcza kiedy intensyfikacji gospodarstw domowych, użytkowników i gmachów nie towarzyszy odpowiednio rozbudowana sieć ulic. Dlatego zbyt wysokie zagęszczenie trudno jest pogodzić ze zróżnicowaniem budynków. Należy dążyć zatem do osiagania optymalnego poziomu zagęszczenia miejskiej struktury - nie za dużego i niezbyt małego (t a m ż e: 228-231, 403-413).

Wypełnienie wszystkich przedstawionych warunków w zamyśle autorki Śmierci i życia wielkich miast Ameryki ma skutecznie przeciwdziałać opanowywaniu miast przez jednorodność. Oprócz wzrostu niebezpieczeństwa i spadku przepływów w mieście wywołuje ona wiele innych niepożądanych następstw. Jeden z poważniejszych skutków wiąże się z powstaniem form przestrzennych, które Jacobs określa mianem pasm przygranicznych. Okalają one wszystkie jednorodne funkcjonalnie przestrzenie miejskie (takie jak dzielnice kulturalne lub administracyjne). Jako przykłady pasm przygranicznych podać można: tory kolejowe, nabrzeża, kampusy, drogi ekspresowe, rozległe parki i parkingi. Ich wspólna cecha, jaką jest „wytwarzanie wokół siebie funkcjonalnej pustki” (t a m ż e: 271), wynika z nadmiernego upraszczania użytkowania miasta na określonym terenie. Pasma przygraniczne, otaczając monofunkcyjne dzielnice, wprowadzają bariery w przestrzeni zurbanizowanej. Sprawiaja, że pewne obszary są jedynie okrążane przez mieszkańców, a nie eksplorowane przez nich (t a m ż e: 269-278).

Innym niekorzystnym następstwem braku różnorodności (i rozprzestrzeniania się przestrzeni przygranicznych) jest intensyfikacja ruchu samochodowego. Choć same samochody w opinii Jacobs nie zasługują na bezwzględne potępienie, to wykorzystywane są one w dzisiejszych miastach w nadmiarze. W celu uporania się z ruchem samochodowym w miastach prowadzonych jest wiele inwestycji. Sprowadzają się one do separacji ciągów pieszych i samochodowych, poszerzania arterii komunikacyjnych, zwiększania liczby miejsc parkingowych. Taka taktyka 
prowadzi jedynie do dodatkowego wyniszczania miasta, gdyż zachęca mieszkańców do korzystania $\mathrm{z}$ aut. Tym sposobem następuje zanik pieszych ścieżek i spada liczba kontaktów między ludźmi (t a m że: 349-374).

Jak wynika z powyższego opisu, zaproponowany przez Jacobs sposób analizy miasta w sposób eklektyczny łączy elementy większości kanonicznych perspektyw teoretycznych socjologii miasta. W stanowisku autorki Śmierci $i$ życia wielkich miast Ameryki dostrzegalne są zarówno komponenty orientacji ekologicznej (analogie organiczne, pragmatyzm), kulturalistycznej (analiza waloryzacji przestrzeni), makrostrukturalnej (relacja stosunków przestrzennych i stosunków społecznych), jak i humanistycznej (analiza życia miasta w perspektywie dramaturgicznej). Jacobs wzbogaciła jednak swoją koncepcję miasta o wymiar manifestu programowego, przykładając szczególną wagę do kwestii takiego kształtowania miejskiej strategii rozwojowej, aby sprzyjała ona występowaniu różnorodności (funkcjonalnej, ekonomicznej, estetycznej, strukturalnej).

\section{Katowicka Strefa Kultury w perspektywie myśli Jane Jacobs}

Powstała w latach 2011-2015 Strefa Kultury jest przez władze Katowic promowana jako nowa wizytówka miasta. Na stronach internetowych Urzędu Miasta można przeczytać, iż „Katowice już dawno przestały być miastem węgla i stali”, a za sprawą inwestycji w dzielnicę kultury stolica Górnego Śląska „staje się czołowym ośrodkiem kultury i turystyki biznesowej w Polsce"4. Do zapewnień tych należy podchodzić z rezerwą. Wcześniejsze doświadczenia stolicy Województwa Śląskiego z adaptacją śródmiejskich przestrzeni poprzemysłowych (kopalni Kleofas, huty Baildon) nie wydają się być szczęśliwe.

Jakie wnioski można zatem wysnuć odnośnie do niedawno przeprowadzonej rewitalizacji terenów po kopalni Katowice? Przytoczone powyżej tezy Jacobs wskazują, że same walory estetyczne i dobre wyposażenie infrastrukturalne nie są gwarantem sukcesu miejskich stref. Choć mogą stanowić pewną atrakcję, to nie musi znajdować to swojego odzwierciedlenia w codziennych praktykach mieszkańców. Znaczenie procesów użytkowania dzielnicy przez mieszkańców jest tym większe, kiedy zdamy sobie sprawę z usytuowania Strefy Kultury (ryc. 1). Stanowi ona niejako przedłużenie ścisłego centrum Katowic. Od strony zachodniej styka się z najbardziej rozpoznawalnym w Katowicach rondem im. gen. Ziętka oraz zmierzającą w kierunku Rynku aleją Korfantego. Od południa sąsiaduje ona z rozległym i wciąż rozbudowywanym kampusem Uniwersytetu Śląskiego i niewielkim osiedlem bloków mieszkalnych. Uniwersyteckie budynki od Strefy Kultury oddzielone są najważniejszą arterią miasta - czyli Drogową Trasą Średnicową (DK 79). Na odcinku przylegającym do nowej dzielnicy DTŚ rozdziela

\footnotetext{
${ }^{4}$ https://www.katowice.eu/miasto/przemiana-katowic/strefa-kultury (dostęp 27.05.2015).
} 
się dodatkowo na dwa pasy biegnące w kierunku tunelu pod rondem oraz dwa naziemne pasy alei Roździeńskiego. Od północy i wschodu Strefa Kultury łączy się z dzielnicą Bogucice. Informacje te będą jeszcze istotne, kiedy przejdziemy do analizy powiązania nowej dzielnicy z resztą miejskiej tkanki.

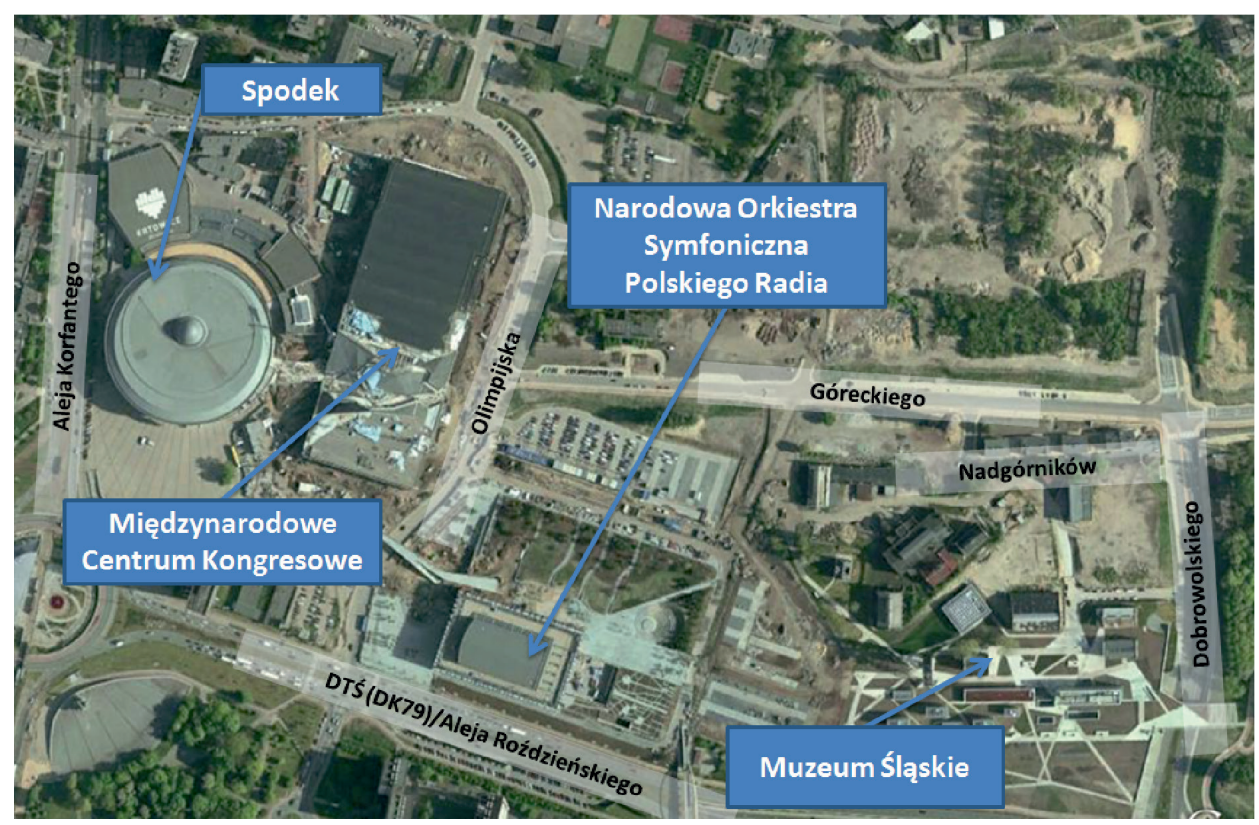

Ryc. 1. Katowicka Strefa Kultury - zdjęcie lotnicze

Źródło: opracowanie autora na podstawie map Google Earth

Zaczniemy jednak od bardziej fundamentalnych spostrzeżen. Wystarczy zapoznać się z ogólnymi danymi o katowickiej Strefie Kultury, aby stwierdzić, że - podług oglądu Jacobs - nie powinna być ona uznana za dobrą dzielnicę. Pierwszą dyskwalifikująca ją cechąjest ogromna skala inwestycji. Opiewająca na ponad 1 miliard złotych suma środków przekazanych na przedsięwzięcie z pewnością spotkałaby się z krytyką ze strony autorki. W ten sposób finansowanie przyczyniło się do wprowadzenia zmian o charakterze skokowym, a nie stopniowym (tamże: 307 ). Drugi „grzech pierworodny” rozpatrywanej przestrzeni wynika z wpisywania się przez nią pod względem formy w założenia ruchu City Beautiful. Strefa skupia monumentalne i wysmakowane architektonicznie gmachy, jest funkcjonalnie odseparowana od reszty Katowic, ulokowana została przy najważniejszych ulicach miasta.

Sytuacja wyda się o wiele bardziej złożona, kiedy na katowicką Strefę Kultury spojrzymy bardziej wnikliwie, przykładając jako szablon analityczny wypunktowane przez Jacobs warunki rozkwitania miejskiej różnorodności. 
Jak pamiętamy, pierwszy parametr dotyczy potrzeby łączenia w ramach dzielnicy zróżnicowanych funkcji. Choć oficjalnie nowa strefa Katowic ma w swojej nazwie kulturę, to oferowana przez nią użyteczność nie jest do końca jednowymiarowa. Znajdujące się w dzielnicy budynki różnią się między sobą pod względem szczegółowego przeznaczenia i trybu funkcjonowania działających w nich instytucji. Otwarte z końcem czerwca nowe Muzeum Śląskie w głównej mierze będzie obiektem wystawowym, przez większość roku otwartym od godzin porannych do popołudniowych. NOSPR jako obiekt stricte koncertowy zazwyczaj zaprasza do siebie mieszkańców w godzinach popołudniowych i wieczornych. W jeszcze inny sposób wykorzystywane będą hale MCK i Spodka. Oferują one możliwość organizowania rocznie od kilku do kilkunastu wydarzeń o charakterze rozrywkowym, sportowym, wystawowym czy też biznesowym.

Powyższe obiekty odznaczają się też pewnym repertuarem funkcji stanowiących o ich różnorodności wtórnej. W siedzibie NOSPR zlokalizowane są księgarnia i restauracja. Spodek oferuje dostęp do pokoi hotelowych oraz restauracji. Pomieszczenia gastronomiczne znajdują się również w nowym Muzeum Śląskim. Przyznać jednak należy, że pod względem punktów usługowych, różnorodność wtórna obiektów Strefy Kultury przedstawia się dość ubogo. Co ciekawe, większe znaczenie w kształtowaniu różnorodności wtórnej przypisać można organizowanym w ramach strefy imprezom okolicznościowym. Wydarzenia, takie jak Dzień Otwarty NOSPR, Noc Muzeów i Industriada w Muzeum Śląskim oraz festiwal Tauron Nowa Muzyka przyciagnęły do nowej dzielnicy tysiące użytkowników przestrzeni.

Skala nowej strefy sprawia, że łatwo przeoczyć pomniejszą oferowaną przez nią użyteczność. Tymczasem w swoich granicach mieści ona szczątkową formę funkcji mieszkalnej. Mowa tu o czterech familokach przy ulicy Nadgórników, czyli w północno-wschodniej krawędzi strefy. Zabudowania te i ich mieszkańcy nie mają jednak prawie żadnego znaczenia dla funkcjonowania dzielnicy kulturalnej. Są one mało rozległe i znajdują się na obrzeżach. Może to oznaczać, że mieszkańcy ci bardziej niż na ofertę nowych obiektów będą się orientować w kierunku położonych po drugiej stronie ulicy Dobrowolskiego Bogucic.

Katowicka Strefa Kultury w sposób niezamierzony obejmuje również tereny przeznaczone na działalność biurową. Mowa tu o działce znajdującej się między MCK a NOSPR. Obecnie znajduje się na niej wyburzany budynek Dyrekcji Okręgowej Kolei Państwowych (DOKP), na którego miejscu prywatny inwestor planuje wybudowanie dwóch wysokich biurowców.

Poczynione tu obserwacje co do funkcjonalnego zróżnicowania dzielnicy nie pozwalają na sformułowanie zbyt optymistycznych wniosków. Prognozować można, że kiedy już ustabilizuje się zainteresowanie obiektami, Muzeum Śląskie będzie przyciagać ludzi do strefy między godzinami porannymi a popołudniowymi. Dalszy przepływ ludności przez dzielnicę będzie zapewniany za sprawą wieczornych koncertów w NOSPR. To jednak wszystko, co dobrego można 
stwierdzić o prawdopodobnej codziennej obecności mieszkańców w Strefie Kultury. Po pierwsze, wszelkie wydarzenia w Spodku i MCK, choć będą udziałem wielu użytkowników przestrzeni, to ze względu na swoją rzadkość nie wpłyną istotnie na codzienne funkcjonowanie dzielnicy. Po drugie, planowane biurowce po upłynięciu godzin roboczych świecić będą pustkami. Sami natomiast pracownicy bardziej niż korzystaniem z możliwości dzielnicy zaabsorbowani będą swoimi obowiazkami. Po trzecie, rozplanowanie funkcji sprawia, że katowicka Strefa Kultury pozostawiona będzie bez społecznego nadzoru w godzinach nocnych. Jest to spowodowane zarówno szczątkową liczbą budynków mieszkalnych, jak i punktów stale przyciągających mieszkańców późnym wieczorem i nocą. Po czwarte, poszczególne znajdujące się w Strefie Kultury obiekty są odseparowane od siebie, i choć będą przyciagać użytkowników w nieco innych porach, to procesowi temu będzie towarzyszyć pustoszenie jednych fragmentów dzielnicy.

Ta ostatnia uwaga przybliża nas do następnego wspominanego przez Jacobs warunku miejskiej różnorodności, czyli znaczenia małych kwartałów zabudowy i często krzyżujących się ulic. Warto rozróżnić tu dwie kwestie: powiązanie dzielnicy jako całości z resztą tkanki miasta oraz odseparowanie poszczególnych tworzących ją inwestycji. Z jednej strony - $z$ uwagi na rozległy charakter przedsięwzięcia - całą katowicką Strefę Kultury można traktować jako jeden rozległy kwartał. Rozciagga się on między aleją Korfantego a ulicą Dobrowolskiego oraz ulicami Olimpijską i Góreckiego a aleją Roździeńskiego. Niestety, niemal trzy krawędzie strefy przyjmują cechy opisywanych przez Jacobs pasm przygranicznych. Południowe połączenie strefy z resztą miasta przecięte jest przez trasę szybkiego ruchu (DTŚ). Bliżej ronda i gmachu NOSPR nie jest jeszcze problemem dla pieszych przedostanie się do dzielnicy lub z niej wyjście. Zapewniają to zlokalizowane blisko siebie przejścia podziemne i przejścia dla pieszych. W miarę przesuwania się na wschód bariera stanowiona przez DTŚ staje się coraz bardziej problematyczna. Na wysokości Uniwersytetu Śląskiego arteria rozszerza się do czterech biegnących równolegle pasów. Wrażenie nieprzystępności dodatkowo spotęgowane jest przez to, że środkowe dwa pasy wychodzą z przebiegającego pod rondem tunelu i znajdują się w zagłębieniu. Choć między kampusem uniwersyteckim a Strefą Kultury przebiega kładka, to nie pojawiają się na niej często przechodnie. Ostatnim punktem, który pozwala pieszym na przemierzenie DTŚ i dostanie się na teren strefy, jest skrzyżowanie ulicy Dudy-Gracza i ulicy Dobrowolskiego. Wiąże się to jednak z pokonaniem kilku przejść dla pieszych. Właściwości pasa przygranicznego przyjmuje także północnowschodnia krawędź strefy. Biegnie tam ulica Góreckiego, która następnie krzyżuje się z ulicami Dobrowolskiego i Nadgórników. Na północ od tej pierwszej ulicy znajdują się zielone nieużytki. Na domiar złego w miejscu tym urywa się ulica Dobrowolskiego. W pierwotnych planach miała ona biec dalej na północ i łączyć Strefę Kultury z dzielnicą Bogucice. Zamiary te nie zostały jednak zrealizowane i nie jest pewne, kiedy dojdą do skutku. Od wschodu kulturalna dzielnica Katowic styka się natomiast z szeroką ulicą Dobrowolskiego i parkiem Boguckim. Wydaje 
się, że najlepsze połączenie z resztą miasta zagwarantowane zostało w obrębie północno-zachodniego i zachodniego brzegu Strefy Kultury. W miejscach tych niejako w naturalny sposób przechodzi ona w otaczające ją zabudowania dzielnic Bogucice (na północ od strefy) i Koszutka (po drugiej stronie Alei Korfantego). Nie zmienia to jednak faktu, że pod względem wkomponowania w resztę Katowic strefa sprzyja intensyfikacji ruchu samochodowego. Jest na tyle rozległa i słabo połączona $\mathrm{z}$ istniejącymi ścieżkami ruchu ludności, że stanowi wyzwanie dla pieszych.

$\mathrm{Z}$ drugiej strony, pewnego komentarza wymaga również sieć połączeń w ramach rozpatrywanej dzielnicy. Już pierwsze spojrzenie na mapę centrum stolicy Województwa Śląskiego pozwala stwierdzić, że liczba krzyżujących się ulic w obrębie Strefy Kultury jest relatywnie niższa niż w przypadku sąsiadujących z nią terenów. De facto w ramach kulturalnej dzielnicy Katowic wyróżnić można trzy główne duże kwartały połączone krzyżującymi się ulicami. Pierwsza i zlokalizowana najbardziej na zachód część obejmuje Spodek, MCK i rozbierany budynek DOKP. Środkowy kwartał zajmowany jest przez NOSPR, przyległy do niego mały park i parking. Gmach nowego Muzeum Śląskiego, wraz z towarzyszącymi mu terenami zielonymi i ogromnym parkingiem, stanowi natomiast wschodnia część strefy. Sytuacji nie ratuje niestety system chodników. W pobliżu NOSPR i MCK, gdzie piesze połączenia z sąsiednimi dzielnicami są dobre, a ścieżki przebiegają blisko ulic, chodniki funkcjonują w miarę normalnie. O wiele gorzej sprawy mają się w części, gdzie zlokalizowane jest muzeum. Największym problemem nie jest jeszcze to, że ścieżki piesze zostały tam odseparowane od ulic, ale że ich przebieg nie jest optymalny. Chodniki otaczające obiekty Muzeum Śląskiego gęsto krzyżują się ze sobą, tworząc skomplikowane kształty geometryczne. Wydaje się, że przesłanką decydującą o ich przebiegu była w pierwszej kolejności wizja estetyczna, a nie ergonomia użytkowania przestrzeni. $Z$ podobną sytuacją mamy do czynienia w przypadku biegnącego przez dach MCK zielonego łącznika między Spodkiem a resztą strefy. Zygzakami wijące się ścieżki z pewnością stanowią pewną atrakcję wizualną, ale utrudniają komfortowe przemierzanie dzielnicy. Przykładowo, w miejscu przecinania się z ul. Olimpijska, przebiegające przez MCK chodniki nie kończą się przejściami dla pieszych.

Trzecia z prezentowanych przez Jacobs własności dobrych, różnorodnych dzielnic dotyczy mieszania się w ich obrębie zabudowy w różnym wieku i stanie. Co ciekawe, analizowana tu katowicka Strefa Kultury w pewnym stopniu spełnia ten warunek. W zachodniej części obejmuje ona otwarty w latach 70. XX wieku Spodek. Pomimo upływu lat obiekt ten jest regularnie remontowany i modernizowany. Zaraz obok jednej z najbardziej rozpoznawalnych hal widowiskowych w Polsce znajduje się wybudowany w zbliżonym czasie biurowiec DOKP. Jak zostało jednak powiedziane, dni tego wysokościowca są już policzone i do końca 2015 roku zniknie on z pejzażu strefy. Na pozostałej po nim działce prywatny inwestor planuje wzniesienie dwóch nowych biurowców (wysokości 50 i ponad 100 metrów). Z jednej strony, wprowadza to pewien ruch w dzielnicy, perspek- 
tywę kolejnych przekształceń. Z drugiej jednak strony, zapowiadane gmachy, kiedy już zostaną wzniesione, powiększą jedynie powierzchnię nowej zabudowy w dzielnicy. Krzyżowanie się „starego” i „nowego” prawdopodobnie najbardziej dostrzegalne jest w przypadku nowego Muzeum Śląskiego. Inwestycja ta bowiem celowo łączy adaptację części pokopalnianych budynków z nowymi przestrzeniami wystawowymi. Przy czym zasadnicza część pomieszczeń ekspozycyjnych ulokowana została pod poziomem gruntu, a jedyną naziemną ich częścią są mało ingerujące w otoczenie prostopadłościenne świetliki. Choć muzeum niedawno otwarło się na zwiedzających, to niektóre pozostałe po kopalni Katowice budynki nie zostały jeszcze poddane renowacji. Będzie to celem kolejnych etapów budowy. Bez watpienia zatem katowicka Strefa Kultury stanowi przykład przedsięwzięcia o ogromnej skali. Pewną nadzieją napawa jednak to, że w dzielnicy będą następować kolejne przekształcenia. Możliwe, że dzięki temu przestrzeń tę ominie problem stagnacji inwestycyjnej.

Zagęszczenie dzielnicy w gospodarstwa domowe oraz ludzi stanowi dla Jacobs ostatnie - czwarte - źródło krzewienia się miejskiej różnorodności. O ile w poprzednich podpunktach analizy wnioski nie zawsze były do końca jednoznaczne, to w tym przypadku z całą odpowiedzialnością można stwierdzić, że rozpatrywana przestrzeń nie spełnia powyższego warunku. W obrębie strefy spotkamy jedynie cztery małe i odseparowane budynki mieszkalne. Równocześnie skupienie zabudowy jest niskie. Ta ostatnia uwaga odnosi się zwłaszcza do wschodniej części dzielnicy, gdzie zlokalizowane jest nowe Muzeum Śląskie. Małemu zagęszczeniu zabudowy towarzyszy duża ilość przestrzeni otwartych - placów, parków i terenów zielonych. Ujmując to bardziej szczegółowo, w strefie znaleźć można dwa duże place (plac pod Spodkiem, plac Wojciecha Kilara), okalający nowe budynki Muzeum Śląskiego deptak, trzy parkingi oferujące łącznie tysiąc miejsc postojowych oraz obsadzone zielenią dziedzińce MCK, NOSPR i Muzeum Śląskiego.

Wobec powyższego opisu warto zadać pytanie o codzienne praktyki wykorzystywania Strefy Kultury przez mieszkańców ${ }^{5}$. Jak na razie, w godzinach roboczych niewiele osób decyduje się na odwiedzenie nowej dzielnicy. Spostrzeżenie dotyczy zwłaszcza przestrzeni nowego muzeum, która w godzinach południowych zwyczajnie jest opustoszała. Między alejkami przylegającymi do prostopadłościennych świetlików nowej galerii wystawowej spotkać można pojedyncze przechadzające się osoby. Sytuacja przedstawia się podobnie na placu wokół NOSPR, gdzie zazwyczaj jedynie kilka osób decyduje się na skorzystanie z lawek czy przyglądanie się fontannie. Zważywszy na rozległość strefy i jej otoczenie przez pas przygraniczny, nie dziwi specjalnie również, że biegnącymi po jej obwodzie ścieżkami rzadko uczęszczają przechodnie. O wiele większe zaintereso-

${ }^{5} \mathrm{~W}$ miejscu tym opieram się na spostrzeżeniach z obserwacji funkcjonowania strefy, których dokonywałem trzykrotnie: 12.05.2015 (godz. 11.30-13.00), 24.05.2015 (godz. 17.00-18.30), 29.05.2015 (godz. 18.00-21.00). 
wanie budzi zielony dach MCK, który oddany został do dyspozycji mieszkańców. Każdorazowo można spotkać tam kilkanaście osób. Część z nich wypoczywa na udostępnionych ławkach, część robi zdjęcia lub ogląda pejzaż strefy. Nieco więcej mieszkańców odwiedza kulturalną dzielnicę Katowic wieczorami i w weekendy. Aktywność ta po części zapewniona jest przez wieczorne koncerty w NOSPR, a po części przez zaciekawienie nową przestrzenią.

W weekend - zwłaszcza w pobliżu zielonego dachu MCK lub fontanny na placu Kilara - spotkać można wielu mieszkańców robiących zdjęcia. Są to osoby, które zdecydowały się na przyjście tutaj jedynie po to, by spędzić czas w mało znanym dotąd otoczeniu. Co jednak będzie, kiedy efekt świeżości przeminie, a użytkownicy przestrzeni zaznajomią się z nową strefą? Istnieje ryzyko, że nie będą już tak chętnie zjawiać się bez wyraźnej przyczyny. Ratunkiem w tej sytuacji może nie być nawet fakt niedawnego otwarcia Muzeum Śląskiego. Zgodnie z prognozami zainteresowanie nowym gmachem $\mathrm{w}$ początkowym okresie funkcjonowania było bardzo duże. W czasie pierwszego miesiąca działania nowej siedziby placówka nie cierpiała z powodu braku zwiedzających. Zwłaszcza w godzinach popołudniowych długie kolejki ludzi ustawiały się do wjazdu na punkt widokowy, zlokalizowany na szczycie szybu Warszawa. Równocześnie podziemne ekspozycje gościły setki zwiedzających. Zaintrygowanie muzealnym gmachem zaczęło maleć już w połowie sierpnia, kiedy zakończył się okres darmowego wstępu do pomieszczeń wystawowych. U progu września popołudniowo-wieczorny ruch ludności wokół nowego gmachu był już istotnie mniejszy niż w poprzednich miesiącach.

Wnioskować można także, że ze względu na sygnalizowaną trudność pieszego dostania się do strefy, odwiedzające ją osoby będą w pierwszej kolejności korzystać z transportu samochodowego. Już w tej chwili zapełnienie parkingów jest wysokie. Nie będzie kłamstwem, jeżeli stwierdzę, że każdorazowo w strefie można spotkać więcej pojazdów niż ludzi. Nie napawa to optymizmem, gdyż świadczy o traktowaniu jej jako ogromnego parkingu przez dojeżdżających do centrum mieszkańców.

\section{Podsumowanie i krytyczna ocena perspektywy analitycznej}

Na zakończenie artykułu warto pokusić się o syntetyczne zestawienie najważniejszych wniosków płynących z zamieszczonej w nim analizy oraz odnieść się do przyjętej płaszczyzny badawczej. Nowa kulturalna strefa Katowic rozpatrywana była przy uwzględnieniu przyjmowanej przez Jacobs perspektywy postrzegania miasta. Zabieg ten można uznać za nieco przewrotny. Autorka Śmierci i życia wielkich miast Ameryki znana jest bowiem ze swojego krytycznego podejścia do modernizmu w urbanistyce, idei miasta-ogrodu, przestrzeni otwartych i parkowych. Tymczasem w stolicy Województwa Śląskiego występuje wiele nawiązań do wymienionych powyżej wizji i form przestrzennych (K o z in a 2009: 11-29; 
Springer 2011: 140-163). Wspomnieć w tym miejscu warto o ufundowanej na idei miasta-ogrodu dawnej zabudowie dzielnicy Giszowiec, modernistycznym Osiedlu Tysiąclecia i kompozycji urbanistycznej w okolicach alei Korfantego. Nie dziwi zatem, że - określające siebie „miastem ogrodów” - Katowice zdecydowały się na wzniesienie monumentalnej, monofunkcyjnej, gęsto obsadzonej zielenią dzielnicy.

Katowicka Strefa Kultury jako ogromna i wpisująca się w nurt City Beautiful inwestycja z pewnością nie spodobałaby się Jacobs. Choć dzielnica nie oferuje do końca jednorodnej funkcjonalności, to okazuje się ona zbyt mało rozbudowana, aby zapewnić równomiernie intensywne wykorzystanie przestrzeni w trakcie dnia i nocy. Kulturalna strefa Katowic ma także problemy ze spełnieniem drugiego - związanego z częstym krzyżowaniem się ulic - warunku wzmacniania różnorodności. Rozległej, usytuowanej koło szerokich arterii i pasów zieleni, dzielnicy towarzyszy uboga siatka ścieżek ruchu. Oznacza to, że niemal z trzech stron strefa otoczona jest przez utrudniające ruch pieszy pasy przygraniczne. Natomiast mało rozbudowana sieć połączeń ulicznych między obiektami nie jest wzmacniana przez ścieżki piesze, które przez większość czasu świeca pustkami. W największym stopniu Strefa Kultury wpasowuje się w przyjmowany przez Jacobs warunek występowania w dzielnicy budynków o różnym wieku i stanie. Obok wyburzanego biurowca DOKP można tu wymienić halę Spodek, część czekających na remont odziedziczonych po zamkniętej kopalni obiektów oraz kilka familoków. Wskazywałoby to zatem, że w najbliższym czasie strefie nie grozi zastój inwestycyjny. Ostatecznie, dzielnica cechuje się także małym zagęszczeniem zabudowy i ludzi. Jest to czwarte - i ostatnie - źródło różnorodności, o którym wspomina autorka opisywanej w artykule książki. Z poczynionych w trakcie opracowywania artykułu obserwacji wynika, że na co dzień dzielnica przyciaga mało użytkowników. Przy czym należy odnotować, że liczba osób odwiedzających strefę wykazuje pewne fluktuacje. Zwiększa się w godzinach popołudniowych, wieczorami oraz w związku ze specjalnymi okazjami - otwarciem nowego muzeum, festiwalami muzycznymi.

Czy zatem należy uznać katowicką Strefę Kultury za dzielnicę martwą? Wskazuje na to wiele spostrzeżeń, na czele z małą liczbą codziennych użytkowników, otoczeniem pasami przygranicznymi i opanowaniem przez samochody. Wydaje się jednak, że powyższa konkluzja byłaby zbyt radykalna. Trudno kwestionować sukces wydarzeń, które dotąd miały miejsce w strefie i pracy znajdujących się w niej instytucji. Sytuacja może się ponadto nieco zmienić in plus, gdy dzielnica ugruntuje się w miejskim pejzażu. Bez wątpienia jednak nowa przestrzeń wymaga uwagi ze strony władz miasta - poprawienia połączeń z otoczeniem, zapewnienia większej liczby atrakcji.

Oczywiście, należy mieć świadomość, że propozycja Jacobs, tak jak każda wizja, poddawana może być krytyce. Zasadne wydaje się pytanie, czy promowany przez autorkę model przestrzeni zurbanizowanej nie przyjmuje cech tak krytyko- 
wanych przez nią projektów miast idealnych. Dokonywana przez Jacobs pochwała ruchu, intensywności miejskiego życia i spontanicznego mieszania się funkcji jest $\mathrm{w}$ dużej mierze jednostronna. Ponadto, odrzucając ontologiczne podstawy XIX-wiecznych utopii, przytaczana działaczka miejska nie podaje konkretnych dowodów na rzecz ludzkiej potrzeby zamieszkiwania w dynamicznym i różnorodnym środowisku miejskim. Tymczasem wyniki najnowszych badań sugerują coś dokładnie odwrotnego. Otwarte zielone przestrzenie pozytywnie wpływają na ludzkie procesy poznawcze i redukują poziom stresu (H oł d y s 2015: 54-59). Zaobserwowano także współzależność między rozległością powierzchni parkowych w miastach a redukcją poziomu przestępczości (B a r b e r 2014: 240-243). Jest jeszcze jeden wątek krytyczny, który warto podjąć komentując zaproponowana przez Jacobs myśl urbanistyczną. Można wysunąć zastrzeżenie, że skupiając się na kwestiach działania chodników, gęstości zabudowy i różnorodności, autorka umniejszyła znaczenie obiektów flagowych w rozwoju miast.

Niezależnie od zarysowanych powyżej nieścisłości, poglądy Jacobs zdają się być adekwatną perspektywą do oglądu katowickiej Strefy Kultury. Dzięki ich zaadoptowaniu możliwe było wypunktowanie głównych mankamentów nowej przestrzeni Katowic.

\section{Bibliografia}

B a r b e r B. (2014), Gdyby burmistrzowie rzadzili światem. Dysfunkcyjne kraje, rozkwitajace mia$s t a$, Wydawnictwo Literackie Muza SA, Warszawa.

Hołdys A. (2015), Miejski mózg, „Wiedza i Życie” 6 (966), Wydawnictwo Prószyński Media, Warszawa, s. 54-59.

J a c obs J. (2014), Śmierć i życie wielkich miast Ameryki, Fundacja Centrum Architektury, Warszawa.

J a łow i e c ki B., S z c ze pań s k i M. S. (2006), Miasto i przestrzeń w perspektywie socjologicznej, Wydawnictwo Naukowe SCHOLAR, Warszawa.

Kozina I. (2009), Katowicka moderna - funkcjonalistyczny epizod dwudziestolecia międzywojennego w Województwie Ślqskim, [w:] O s lis l o Z. (red.) (2009), Katowicka Moderna 1927-1939, Wydawnictwo M-Studio, Zabrze, s. 11-29, http://opac.ciniba.edu.pl/Scripts/ cgiip.exe/wo2_opbib.p?ID1=IKNMMOLGRPGJODGHFSQMK\&ln=pl\&RODZAJ=1\&ID= $455100 \&$ widok $=19 \& N 1=\mathrm{W} 15005541 \& \mathrm{~N} 2=1 \& \mathrm{~N} 3=19 \& \mathrm{~N} 4=\mathrm{KHW} \& \mathrm{HN} 1=1000612211353 \&$ $\mathrm{HN} 2=4 \& \mathrm{HN} 3=192303545615$

M a j e r A. (2010), Socjologia i przestrzeń miejska, Wydawnictwo Naukowe PWN, Warszawa.

P a s z o w ski Z. (2011), Miasto idealne w perspektywie europejskiej i jego zwiazki z urbanistyka wspótczesna, Wydawnictwo Universitas, Kraków.

Pobłocki K. (2014), Jane Jacobs - urbanistka przyziemna. Postowie do wydania polskiego, [w:] J a c o b s J. (2014), Śmierć i życie wielkich miast Ameryki, Fundacja Centrum Architektury, Warszawa, s. 459-475.

Springer F. (2011), Źle urodzone. Reportaże o architekturze PRL-u, Wydawnictwo Karakter, Kraków. 


\title{
Piotr Czakon
}

\section{A NEW DEAD DISTRICT? KATOWICE CULTURE ZONE IN THE PERSPECTIVE OF JANE JACOBS' URBAN CONCEPT}

\begin{abstract}
The article's main subject is the Culture Zone in Katowice - a new district established in an area of the now-closed coal mine called "Katowice". Katowice Culture Zone consists of: a well known "Spodek" arena, recently opened The Polish National Radio Symphony Orchestra complex, International Congress Centre and new buildings of The Silesian Museum. The new buildings gained recognition and appreciation in the architects' community. However, there are also negative opinions about the way the whole project was executed. Some critics complain about the fact of concentrating buildings of similar function in a close-by area. It has been pointed in the article that the new district was designed according to the modernist paradigm in urbanism (functional separation, loose density of buildings). There is nothing unusual about it considering past modernist influences in the city architecture. Nevertheless, the social consequences of modernistic urban planning are way more important, as it has been pointed out by the critics. A special place among them belongs to Jane Jacobs, an author of a famous book: The Death and Life of Great American Cities. In the article, the public space of Culture Zone in Katowice was analyzed according to Jacobs' thesis. Several issues have been discussed: layout of buildings and streets or a functional variety. Unfortunately, conclusions of the research are not optimistic. The Culture Zone is separated from rest of the city and lacks diversity. It also suffers lack of citizens' interest.
\end{abstract}

Key words: Katowice Culture Zone, Jane Jacobs, revitalization, public space. 